\title{
Antioxidant activity and production of secondary metabolites of adult plant and in vitro calli of Anodendron paniculatum
}

\section{K. Nagendra Prasad}

Department of Botany K.T.S. Government Degree College, Rayadurg, Anantapur (Andhra Pradesh), India

G. Kranthi Kumar

Department of Botany, KBN College, Vijayawada (Andhra Pradesh), India

\section{Raghu Ram*}

Department of Botany and Microbiology, Acharya Nagarjuna University, Guntur (Andhra Pradesh), India

*Corresponding author. E-mail: mraghuram2002@gmail.com

\begin{abstract}
The members of the family Apocynaceae are the rich in alkaloids, terpinoids, flavonoids, phenolic compounds and hydrocarbons. Anodendron paniculatum Roxb. is an woody climber, the roots of which have been used to control vomiting and cough. In the present study, adult plant and tissue culture plant extracts of $A$. paniculatum collected from Eastern Ghats, Araku, Andhra Pradesh were used for the production of their secondary metabolites and antioxidant activity. Methanol extracts of calli showed high contents of total phenol and alkaloid with 25.53 and $25.98 \mathrm{mg} / \mathrm{g}$ respectively. Methanol extract of tissue culture plant at higher concentrations showed better antioxidant activity with reference to standard ascorbic acid. For this study different concentrations $(12.5,25,50,100$ and 200 $\mu \mathrm{g} / \mathrm{ml}$ ) of extracts were prepared by using four different solvents. Tissue culture extracts from methanol showed maximum scavenging activity with $231.9 \pm 1.39 \%$ at $200 \mu \mathrm{g} / \mathrm{ml}$ of concentration, while that of adult plant extracts showed the scavenging activity of $189.1 \pm 0.74 \%$ only. These results on high antioxidant activity of the methanol extract of $A$. paniculatum calli can be attributed to the presence of high phenolic and alkaloid contents in calli when compared to that of adult plant extract.
\end{abstract}

Keywords: Alkaloids, Anodendron paniculatum, Antioxidant activity, Apocynaceae, Phenols

\section{INTRODUCTION}

Genus Anodendron belongs to the subfamily Apocynoideae, family Apocynaceae (Takhtajan 2009) with 17 species (Middleton 2007). It is naturally distributed in India, Japan and South China. Anodendron consists of 19 species covering a large area of India, a few speices of Anodendron namely Anodendron benthamianum, $A$. howii, $A$. punctatum, $A$. affine, and $A$. formicinum (Flora of China Editorial Committee 1995).

Much of the earlier works on antioxidant activity from members of the family Apocynaceae were concentrated on extracts from areal parts of the plant while the work related to callus extracts was very meagre. The previous records on antioxidant activity of the members of Apocynacea include Anbukkarasi et al, (2016) on Tabernaemontana divaricata leaves; Bhadane and Patil, (2017) on Carissa carandas leaves; James et al (2011) on flower extract of Alstonia scholaris; and Ganapathy et al., (2011) on plant extract of Holarrhena

\section{Article Info}

https://doi.org/

10.31018/jans.v11i3.2132

Received: June 20, 2019

Revised: August 19, 2019

Accepted: August 25, 2019

\section{How to Cite}

Nagendra Prasad K. et al. (2019). Antioxidant activity and production of secondary metabolites of adult plant and in vitro calli of Anodendron paniculatum. Journal of Applied and Natural Science, 11(3): 632- 635 https://doi.org/ 10.31018/jans.v11i3.2132 
were used for callus induction in the present study. MS medium supplemented with $2 \mathrm{mg} / \mathrm{ml}$ of 2-4 D + $0.5 \mathrm{mg} / \mathrm{ml}$ Kinetin was used as callus induction medium (CIM). Leaf discs, after sterilization, were cut into 2-3 $\mathrm{mm}$ pieces using a sterile scalpel. The cultures were incubated for 6 weeks in $16 \mathrm{~h}$ light and $8 \mathrm{~h}$ dark at $25 \pm 2^{\circ} \mathrm{C}$ and tissues developed were observedfor callus production at 3 week intervals.

Callus extract: The callus was dried first by freeze drying using a dryier and then powdered. The dried powder was extracted with four different solvents, petroleum ether $\left(60-80^{\circ} \mathrm{C}\right)$, chloroform, ethyl acetate, and methanol in a Soxhlet apparatus.

Preparation of callus crude extract: The dried A. paniculatum plant material of $20 \mathrm{~g}$ weight was cleaned and ground to fine powder using a mortar and pistil. The fine poweder was packed tightly in a soxhlet extracter and extraction was done using $200 \mathrm{ml}$ of petroleum ether. The extraction process was carried out for $6 \mathrm{hrs}$. Similarly using other solvents also the extractions were made and the final extracts obtained were evaporated by Roto evaporation under reduced pressure at $60{ }^{\circ} \mathrm{C}$ to get a solid dry product which was stored in dried bottles for further use.

Quantification of total phenolic content: The determination of the phenolic content followed the method of Singleton et al., (1999). The amount of phenols in the extract was expressed in terms of gallic acid equivalents (mg of $\mathrm{GA} / \mathrm{g}$ of extract) by using the calibration graph and the absorbance recorded for the extract.

\section{Quantification of total alkaloid content}

Preparation of solutions: Caffeine standard solution was prepared by dissolving $1 \mathrm{mg}$ pure atropine (Sigma USA) in $10 \mathrm{ml}$ distilled water (Shamsa et al., 2008).

Standard curve: Different standard Aliquots (0.4, $0.6,0.8,1$ and $1.2 \mathrm{ml}$ ) of atropine were prepared and separatedto funnels. To this $5 \mathrm{ml}$ of phosphate buffer and $5 \mathrm{ml}$ of BCG solutions were mixed with $4 \mathrm{ml}$ of chloroform. The extracts were collected in a $10 \mathrm{ml}$ volumetric flask and then diluted to adjust volume with chloroform. The absorbance of chloroform was measured by using spectrophotometer at $470 \mathrm{~nm}$. Blank was prepared without atropine.
Antioxidant activity of DPPH free radical scavenging: The DPPH activity was carried out as described by Bidchol et al., (2009) with slight modifications. $0.1 \mathrm{ml}$ of extract containing $3 \mathrm{ml}$ of DPPH solution $(0.1 \mathrm{mmol} / \mathrm{L}$ in $95 \%$ ethanol $\mathrm{v} / \mathrm{v})$ and this was shaken thoroughly, incubated for 30 minutes at room temperature. The readings were measured by using spectrophotometer at $517 \mathrm{~nm}$ with standard Ascorbic acid.

The radical scavenging activity was measured as decrease in the absorbance of DPPH and calculated using the following equation. The percent DPPH scavenging effect was calculated by using following equation:

DPPH scavenging effect (\%) or Percent inhibition $=A 0-A 1 / A 0 \times 100 . \quad \ldots \ldots . . . . E q .1$

Where $A 0$ was the Absorbance of control reaction and $A 1$ was the Absorbance in presence of test or standard sample.

Statistical analysis: The data are presented as mean \pm SE of 15 explants per treatment and it was taken from the average of three replicates. . Data were statistically analysed using Duncan's multiple range test and found significant if $P \leq$ 0.05 .

\section{RESULTS AND DISCUSSION}

Phytochemical screening of $A$. paniculatum adult plant extract revealed that out of the four different solvents used, methanolic extract showed high content of alkaloids and phenolic compounds (Tables 1 and 2). Highest phenolic content was observed in callus extract with $25.53 \mathrm{mg} / \mathrm{g}$ of gallic acid equivalent of callus extract, when compared to that of adult plant extract with $20.62 \mathrm{mg} / \mathrm{g}$. Similarly, highest alkaloid content of $25.98 \mathrm{mg} / \mathrm{g}$ of AE/ $\mathrm{g}$ was observed in callus extract when compared to that of adult plant extract in which $21.19 \mathrm{mg} / \mathrm{g}$ of $\mathrm{AE} / \mathrm{g}$ was recorded.

The calli of Anodendron showed similar results as of aerial parts with high contents of total phenol and alkaloid. Methanol extracts of calli showed high contents of total phenol and alkaloid with $20.62 \mathrm{mg} / \mathrm{gm}$ and $21.19 \mathrm{mg} / \mathrm{gm}$ respectively, followed by chloroform, ethyl alcohol and petroleum ether respectively. As this plant is rare, medicinally valuable, and specific to its habitat condition, and its indiscriminate usage for the production of secondary metabolites which may lead to the ex-

Table 1. Total phenolic and alkaloid contents $(\mathrm{mg} / \mathrm{gm})$ of the adult plant and callus extracts of Anodendron paniculatum.

\begin{tabular}{|c|c|c|c|c|c|}
\hline \multirow{2}{*}{$\begin{array}{l}\text { S. } \\
\text { N. }\end{array}$} & \multirow{2}{*}{$\begin{array}{l}\text { Name of the } \\
\text { extract }\end{array}$} & \multicolumn{2}{|c|}{$\begin{array}{l}\text { Adult Plant } \\
\end{array}$} & \multicolumn{2}{|c|}{$\begin{array}{c}\text { Callus } \\
\end{array}$} \\
\hline & & $\begin{array}{l}\text { Total alkaloid } \\
\text { content (mg/gm) }\end{array}$ & $\begin{array}{l}\text { Total Phenolic } \\
\text { content (mg/gm) }\end{array}$ & $\begin{array}{l}\text { Total alkaloid } \\
\text { content }(\mathrm{mg} / \mathrm{gm})\end{array}$ & $\begin{array}{l}\text { Total Phenolic } \\
\text { content }(\mathrm{mg} / \mathrm{gm})\end{array}$ \\
\hline 1 & Petroleum ether & $9.02 \pm 3.52$ & $8.11 \pm 0.33$ & $9.02 \pm 3.52$ & $8.11 \pm 0.33$ \\
\hline 2 & Ethyl acetate & $11.62 \pm 0.48$ & $12.41 \pm 1.20$ & $11.62 \pm 0.48$ & $12.41 \pm 1.20$ \\
\hline 3 & Chloroform & $18.11 \pm 1.16$ & $17.89 \pm 1.33$ & $18.11 \pm 1.16$ & $17.89 \pm 1.33$ \\
\hline 4 & Methanol & $21.19 \pm 1.33^{*}$ & $20.62 \pm 1.99^{*}$ & $25.98+2.09^{*}$ & $25.53+1.89^{*}$ \\
\hline
\end{tabular}




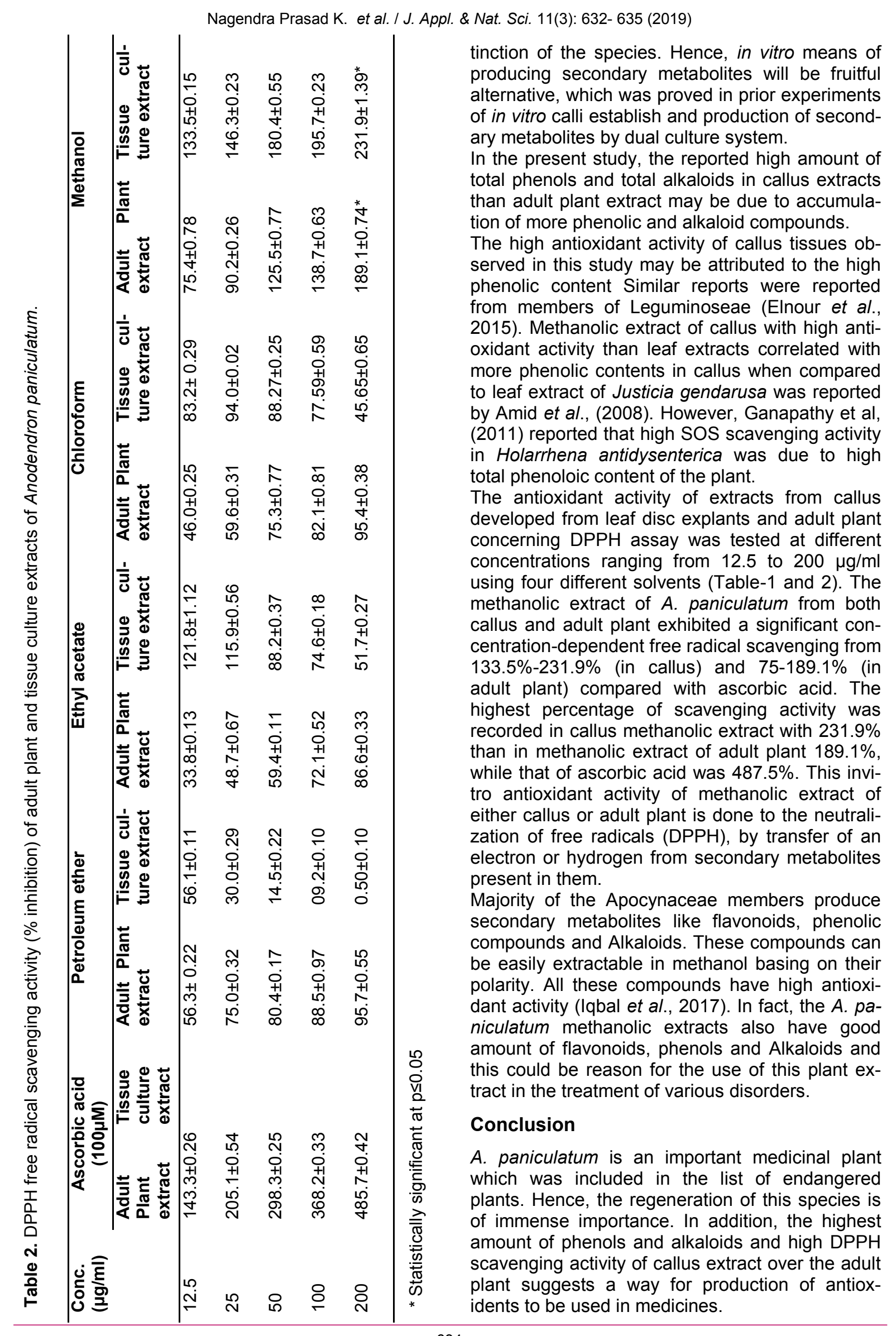




\section{ACKNOWLEDGEMENTS}

First author, K. Nagendra Prasad is thankful to the Department of Botany, K.T.S. Government College, Rayadurg, Anantapur, and second author G. Kranthi kumar is thankful to KBN College, Vijayawada The authors are thankful to the Dept. of Botany \& Microbiology, Acarya Nagarjuna University for providing necessary facilities to complete this research work.

\section{REFERENCES}

1. Amid, A., Johan, N.N., Jamal, P. and Zain, W.N.W.M., (2011). Observation of antioxidant activity of leaves, callus and suspension culture of Justicia gendarusa. African Journal of Biotechnology, 10(81):18653-18656. DOI: 10.5897/ AJB11.2734

2. Anbukkarasi, M., Thomas, P. A., Sundararajan, M., and Geraldine, P. (2016). Gas chromatographymass spectrometry analysis and in vitro antioxidant activity of the ethanolic extract of the leaves of Tabernaemontana divaricata. Pharmacognosy Journal, 8(5) : 451-458.

3. Bhadane, B. S., \& Patil, R. H. (2017). Isolation, purification and characterization of antioxidative steroid derivative from methanolic extract of Carissa carandas (L.) leaves. Biocatalysis and Agricultural Biotechnology, 10, 216-223.

4. Bidchol, A.M., Wilfred, A., Abhijna, P. and Harish, R., (2011). Free radical scavenging activity of aqueous and ethanolic extract of Brassica oleracea L. var. italica. Food and Bioprocess Technology, 4(7):1137-1143. DOI 10.1007/s11947-0090196-9

5. Chi, V.V. (1997). Dictionary of Vietnam Medicinal Plants. Medical Publishing House, Hanoi.

6. Elnour, M.E., Ali, A.M. and Saeed, B.A.T. (2015). Effect of different concentrations of auxins and combination with kinetin on callus initiation of
Trigonella Foenum-Graecum. L. Int. J. Technic. Res. Appl, 3(2):117-122.

7. Flora of China Editorial Committee (1995). Flora of China (Gentianaceae through Boraginaceae). Volume 16. Flora of China Press \& Missouri Botanical Garden Press, Beijing and St.Louis.

8. Ganapathy, P. S., Ramachandra, Y. L., \& Rai, S. P. (2011). In vitro antioxidant activity of Holarrhena antidysenterica Wall. methanolic leaf extract. Journal of Basic and Clinical Pharmacy, 4(4), 175.

9. Harborne, J.B. and Williams, C.A. (2000). Advances in flavonoid research since 1992. Phytochemistry 55 : 481-504. DOI.org/10.1016/S0031-9422 (00)00235-1

10.lqbal, Z., Iqbal, M.S. and Mishra, K., (2017). Screening of antioxidant property in medicinal plants belonging to the family Apocynaceae. Asian J Pharm Clin Res, 10(12):415-418. DOI: http://dx.doi.org/10.22159/ajpcr.2017.v10i12.22 303

11.James, J., Veettil, A. K. T., Pratyush, K., Misra, C. S., Sahadevan, L. D. M., \& Thankamani, V. (2011). In vitro antioxidant activity of flowers and fruits of Alstonia scholaris. International Journal of Phytomedicine, 3(4), 475- 479.

12.Middleton DJ., Flora Malesiana. (2007). Series I, Volume 18. Foundation Flora Malesiana, Netherlands.

13.Shamsa, F., Monsef, H., Ghamooshi, R. and Verdian-rizi, M., (2008). Spectrophotometric determination of total alkaloids in some Iranian medicinal plants. Thai J Pharm Sci., 32:17-20.

14.Singleton, V.L., Orthofer, R. and LamuelaRaventós, R.M., (1999). Analysis of total phenols and other oxidation substrates and antioxidants by means of folin-ciocalteu reagent. In Methods in Enzymology, 299: 152-178. doi.org/10.1016/ S0076-6879(99)99017-1

15.Takhtajan, A. (2009). Flowering plants. Springer, St. Petersburg. 